\title{
HOW BODY IMAGE AFFECTS CANCER PATIENTS' COPING WITH THE DISEASE: BASED ON WILLIAMS LIFESKILLS PROGRAMME EXPERIENCES
}

\author{
Csilla Száva, Csaba Dégi \\ Babeș-Bolyai University, Faculty of Sociology and Social Work
}

\begin{abstract}
The image we create of ourselves functions as some imprint in our lives and influences our mindset and coping mechanisms. Nowadays, there is a growing number of research addressing the adverse outcomes that inappropriate or unrealistic body image may have in the recovery process of chronic patients. Part of society takes the view that cancer is a death warrant in itself. These factors represent an immense source of stress for them that they must take on day by day. However, while going through this process, they need to have resources ready to tap into their inner resources. The research at hand presents the effectiveness of the promotion and application of the Williams LifeSkills Programme concerning coping mechanisms (Stauder, 2016), which contributes to the stress management of people suffering from the effects of cancer, to making their coping more effective and developing their social skills. In the program, participants were allowed to learn strategies and master techniques whose application serves as a more efficient way to address their current needs. The Williams LifeSkills Programme has never been used before with oncology patients in Romania, only in the territory of Hungary (Rohánszky, 2021). In terms of body image assessment, this skills development program was used to consider a new perspective, wherein essential connections were revealed concerning coping methods. To positively influence participants' self-acceptance
\end{abstract}

and body image, particular emphasis was placed on inserting music and dance choreographies into the activities, which, besides creating a community experience, served to relieve inner tension and channel the stress. A group of 11 cancer survivor patients took part in the life skills development intervention. The mental health intervention led to improvements in shifting the group's coping mechanisms at the cognitive level. Based on results obtained at the end of the intervention period, group members favored cognitive restructuring over the initially adopted stress-reduction method. Professionally speaking, we consider it essential that this skills development program be applied in cancer support groups since people struggling with the effects of the disease require cognitive assistance in their problem solving and stress management, just as healthy individuals are.

Keywords: body image, self-esteem, modes of coping, stress reduction, cognitive restructuring

\section{Introduction}

Body image is essentially the basis of self-esteem (Riskó, 1999). 'Knowledge of our body is a mental performance or phenomenon that forms part of the self and is also something that the self reacts to as well. As the basis of personality, one takes this as a starting point to build on when organizing their behavior and activities' (Kende, 2002: 111).

\footnotetext{
* Corresponding Author: Szava Csilla, Babeș-Bolyai University, Faculty of Sociology and Social Work, Email: szavabirocsilla@gmail.com

Article received: 17.07.2021, accepted: 15.09.2021, published: 20.10 .2021

Cite: Szava Cs, Degi Cs. How body image affects cancer patients' coping with the disease: based on Williams LifeSkills Programme experiences. The Journal of School and University Medicine 2021;VIII(3): $43-60$
} 
Body image thus refers to the body as a psychological experience, and identification with the image seen lays the groundwork for the formation of the self - this way, the concepts of identity, sameness, and distinctness will be settled in the individual (Kende, 2002). The lesion causing an aesthetic problem often heals up, yet the individual feels unattractive and deformed (Szabó, 2010). However, satisfaction with body image impacts patients' quality of life and thus may also influence their health (Micskei, 2014). The different appearance or some deficiency of the body leads to the vulnerability of the representation of one's own body, which affects the process of identity construction: 'The disintegration of personality takes place due to functional changes in the body schema' (Kende, 2002: 129). Research suggests that if we cannot successfully integrate our changed body image into our self-image, the immune response will decrease in the rejected body part after depersonalization. Accordingly, the pain threshold gradually decreases with the decrease in temperature of the given body part, resulting in more inadequate blood circulation and lower homeostasis (Kállai, 2013).

\section{Risk factors of developing a negative body image among cancer patients}

During their adaptation to the disease, patients need to re-evaluate their attitude towards their own body (Csabai, 2009). This process manifests itself through some sort of interaction with ourselves (Kállai, 2013). Our body image reflects the way we perceive our physical functions and appearance (Cash, 2004). Psychological reactions induced by changes in the body image do not depend primarily on the magnitude or visibility of the change but the patient's premorbid personality, narcissism, and adaptability (Csabai, 2009). What is more, the chronic disease that also involves changes to one's outward physical appearance has a rather destructive impact on one's body image and body satisfaction in addition to its negative influences on the quality of life (Micskei, 2014). 'Amputation as a loss can be viewed as a traumatic event since losing a body part causes severe physical as well as mental trauma to a person, which they are often unable to process. If this happens, they lose their self-esteem, dreams, and belief in achieving their goals if they insist on pursuing them' (Pongrácz, 2014: 110). Research reports that the greater subjective value is attached to the lost body part, the more severe anxiety and negative changes related to the body will develop among the patients (Panyi, 2015). Therefore, it is much easier to have them accept a post-surgery situation where only a temporary anatomical or functional limitation occurs (Horti, 2017). Gynecological surgeries often reduce the sense of femininity, having negative consequences on body image and self-esteem. Breast surgeries, ovarian sterilization, and hysterectomy can all lead to a sense of diminished value. The breast is the symbol of femininity, motherhood, and sexual attractiveness. Therefore, breast surgeries often involve more psychological severe consequences than genital surgeries do. Individuals more sensitive in this regard may develop social embarrassment or disgust in connection with the operated body. Hence, the probability of experiencing a trauma also depends on the particular female patient's physical self-assessment (Riskó, 1999). During coping processes, amputees must integrate their changed body image into themselves to adapt to the resulting situation (Panyi, 2015). Nevertheless, adapting to the changed body appearance can last even as long as a year (Csabai, 2009).

Patients unable to adapt to the new reality have 'live' experiences with themselves, but they also preserve their entire body image in their minds. These two separate sets of experiences usually never become one. Keeping apart the actual stored body image requires extra energy from the patients (Riskó, 1999). Failure to recognize and accept reality is, in fact, part of a psychological defense mechanism and a form of denial. Phantom pain that arises following the amputation plays the psychological role of obliterating this unacceptable 'crack' in the body image. Árpád Mezei believes that this body image disorder occurring in patients may complicate the disease process (based on Riskó, 1999).

\section{Anxiety and self-esteem disorders}

As Kinga Pongrácz (2014) formulates it, the self-esteem of people with disabilities is difficult to change. The truth behind this also applies to the case of cancer patients who have undergone amputation: 'They firmly believe that they are unable to control 
their destiny, wherefore they are more critical of themselves and feel less valued' (Pongrácz, 2014: 132). Another research reports on the predictive nature of body dissatisfaction and anxiety concerning the appearance of depressive symptoms, both of which were found in correlation with lower levels of well-being and life satisfaction (Panyi, 2015).

\section{Social isolation and sexual disorders}

Adverse changes in the body image result in a lower activity level, while a positive body image involves more physical activity. Panyi and Lábadi's (2015) study revealed that a negative body image is developed following the loss of a limb, which resulted in a lower general activity level and gave rise to difficulties in global adaptation among amputated individuals. Further, changes occurring in patients' body image and bodily functions correlate with cancer patients' relationships and sexual disorders (Riskó, 1999).

\section{Techniques to improve body image}

Physical therapy for cancer patients is beneficial not merely from a physiological but from a psychosocial aspect while also improving patients' quality of life (Horti, 2017). Physical therapy used for psychotherapeutic purposes facilitates the acceptance of body image, has anti-anxiety effects, and plays a role in regaining control over the body and mitigating the adverse reactions of the disease. It influences the activation of self-power while contributing to the improvement of patients' sense of reality. Its mood-enhancing properties are unique, and it has beneficial effects on maintaining psychosomatic balance. In the physiotherapeutic intervention, a positive, emotional relationship is created between patient and therapist. Taking part together in a physical activity favors adaptation, thus improving the quality of human relationships damaged due to the consequences of the disease (Riskó, 1999). Dancing or sports activities that take place in front of the mirror have body-image-enhancing and self-esteem-boosting effects on individuals with low self-esteem or struggling with body image disorders (Pongrácz, 2014). Several research studies have shown the role of aerobics in accepting one's body image and physical appearance. Research points out that, besides providing a sense of companionship, aerobics motivates people while ensuring a non-competitive environment for them. Results suggested reduced dissatisfaction with body image and increased self-acceptance and self-esteem (Sági, 2012). Hausenblas and Fallon's (2006) meta-analysis indicates that positive changes in the body as a result of physical exercises as well as an enhanced sense of self-efficacy experienced through physical activities produce an improved body image. As a result of physical exercises, people tend to feel stronger, slimmer, more toned, and firm; these perceived physical changes can improve body image regardless of the objective physical changes (Depcik, 2004). Aerobics' protection factor against stress has also been demonstrated as follows: 'Analysing a sample population of 1,000 university students revealed that the 11-weeklong aerobic training was more effective in reducing the depressant effects of stressful life events when compared to relaxation training' (Kállai, 2013: 275).

The favorable impact of physical exercise plays a part in the risk of disease development as well. According to a 2010 research, physical training reduced the risk of developing cardiovascular diseases, diabetes, and certain types of cancer (Béres, 2013: 92).

\section{Stress and ways of coping with stress among cancer patients}

The assessment of stress takes consideration of three theoretical approaches. Based on the environmental approach, the exploration and assessment of stressors are performed (Holmes, 1967). The psychological approach considers the individual's stress assessment processes and coping responses (Lazarus, 1984). Finally, the biological approach takes a physiological perspective on the responses given to stressors (Selye, 1956). Modern-day stress research favors the psychological approach, which addresses subjective responses given to stress (Cohen, 1985).

Depending on the duration of stress effects, we may speak about acute or severe and mild or chronic stress (Kopp, 2004). Just as the sources of chronic stress present in the workplace and interpersonal relationships or emerging due to various disabilities, chronic diseases also have a role in developing an increased risk of persistent stress (Rosengren, 2004; Williams, 2010). Initially, our body adapts to stressful life events. In the early stages of stress reaction, our 
body produces stress hormones, blood pressure, and blood sugar rise. Later, however, our body is overloaded and enters the exhaustion stage, where it can no longer adapt to the situation at hand. The imbalance thus created may now be accompanied by disease symptoms. This process largely depends on individuals' level of stress resistance and stress management abilities. Maladaptive stress management behaviors may appear with individuals who fail to adapt, which may be reflected in smoking, abnormal alcohol consumption, or eating disorders properly. Therefore, it is essential to replace these behaviors that are harmful to health with other alternative conflict management and stress relief strategies (Ursin, 2004). Psychosocial factors determine the attitude towards different situations and the level of perceived stress.

Consequently, an individual's way of coping is not only a matter of hereditary factors. Social and economic background, educational attainment, family and cultural patterns, former experiences, and mindset can also contribute to coping strategies. But all the above are the result of a complex learning process (Stauder, 2007).

Coping is an intentional physical or mental response to stress. It aims to change the environment or our internal states. We can manage when the person feels that their currently available resources are insufficient for adaptation (Oláh, 2005). Within the process of coping, a distinction is made between the role of primary and secondary control. While primary control is an effort to change the environment, secondary control seeks to maximize the person's self-directed, inner resources against stress. Secondary control performs the function of self-regulation in people's lives (Weiss, 1994).

As postulated by Lazarus and Folkman (1984), the assessment of the different factors depends on the individual, wherefore the modes of coping also vary from person to person. Based on the authors' cognitive transactional model, a transaction, i.e., an active interaction, changes the strainful circumstances when someone faces a stressful situation. Again, the coping process takes place on two levels and is based on a cognitive appraisal. As a first step, the individual assesses the subjective significance of the situation at hand. During the secondary assessment, one becomes aware of how one can cope with the threatening situation.
If we can assess our perceived abilities correctly and following the expectations of the relevant environment, then, as a result, we will experience competence. Competence is the ability to control our situation, and experiencing it is termed personal effectiveness by Bandura (1982). This way, the level of stress experienced depends on both the person's cognitive appraisal and coping ability. Uncontrollable stress is essentially pathological stress. Under this approach, the concept of potential stressors indicates the person-dependent nature of the experienced stress level (see Figure 1 based on Lazarus and Folkman, 1984).

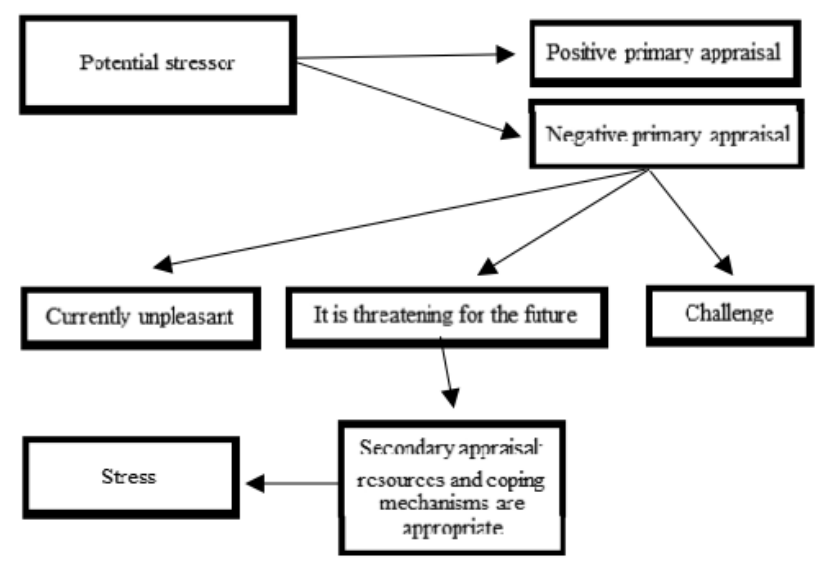

Figure 1. Lazarus and Folkman's theory of stress (see Dávid, 2014: 69)

When we cannot control a specific stressful situation, then a state of imbalance will set in. As a consequence, we reappraise our case, where we assess whether it can be controlled through activity or not. Coping responses that can be held through action fall under two categories: adaptive and non-adaptive responses. As mentioned above, non-adaptive/maladaptive responses include substance abuse, aggression, suicide, and increased blood pressure. Non-adaptive responses, which cannot be controlled through activity, comprise anxiety-based stomach problems, depression, and learned helplessness. Self-image showing a stable development and authentic feedback from the environment can, however, make a positive contribution to the effective coping processes (Kopp, 2001).

Lazarus and Folkman (1984) mention two coping strategies, which are not separated from each other. In problem-focused coping, the individual attempts to 
find some resolution to the situation or problem they face. In emotion-focused coping, they seek to reduce the adverse emotional reactions experienced in a stressful situation. Mária Kopp and Árpád Skrabski (1995) distinguish seven coping factors, which also provide the basis for the Ways of Coping Inventory (Rózsa, 2008). Our skills development intervention is built upon this theoretical approach. The first step adopted in this self-report questionnaire is problem analysis, which belongs to problem-oriented solutions. Adaptation (e.g. yield or negotiate), seeking emotional balance (e.g. distance oneself from the problem), emotionally motivated actions (e.g. taking out one's tension on others), retreat (e.g. hiding the problem from others), and asking for help (e.g. seeking the help of a relative or a professional) are all coping strategies that belong to emotional problem-solving. Individuals who can ask for help and accept the compassion of others usually go through stressful situations much faster and more successfully. Problem-focused coping, too, plays a significant part in overcoming difficulties with a more positive outcome. Dombeck and Wells-Moran (Dombeck, 2006 - qtd. in Petkova, 2020) assigned a lower level of effectiveness to emotion-focused strategies. Medium-level strategies are again less efficient in coping because, in problem situations, they focus on retreating. Owing to the solution-seeking approach, high-level strategy (e.g. taking responsibility, reframing, or seeking support) include cognitive elements, which places them among the most efficient coping strategies (Dávid, 2014).

Surveys indicate that individuals with low self-esteem are more prone to resort to retreating and distancing as a reaction to situations threatening them (Csabai, 2009). Optimistic persons tend to focus on the problem, whereas pessimistic individuals mostly opt for emotion regulation strategies (Szondy, 2006; based on Carver-Scheier, 1998).

\section{A presentation of the Williams LifeSkills Programme}

The application of behavioral medicine programs (e.g. Williams LifeSkills Programme) comprises health promotion, healing, and rehabilitation (Chan, 2015). Community or individual-level interventions are much more efficient than those designed to address a significant number of people. In addition to stress management training, these are aimed at developing individuals' coping skills. Most of them take a cognitive/behavioral therapy approach and apply relaxation training as well. Virginia Williams and Redford Williams developed the Williams LifeSkills Programme, members of the Duke University staff, the program has been in use in the U.S. and Canada since 1991. The colleagues of the Institute of Behavioural Sciences at Semmelweis University elaborated the Hungarian version of the program in 2004 (Williams \& Williams, 2006), and it has been made available in the Hungarian language since 2007 - it also includes a self-help book, an educational film, and an information website (www.williamslifeskills.com). To be in complete alignment with the needs of the various target groups, the Hungarian-language DIÁK-WÉK, PED-WÉK, and DUCI-WÉK programs were developed. DIÁK-WÉK introduces conflict situations characteristic of adolescence and outlines some attempts at finding solutions for them in the light of the WÉK strategy. It can be used effectively with fast learners, students struggling with various issues, and those coming from multiply disadvantaged backgrounds alike. PED-WÉK is mainly concerned with conflict resolution strategies addressing problems arising in the course of educational work. Finally, DUCI-WÉK deals with overweight issues deriving from maladaptive eating habits. It devotes particular attention to coping with negative mood states and stress management, where inadequate control can often be the underlying cause for abnormal eating habits (see Stauder, 2016).

The opening topic of the Williams LifeSkills Programme is self-knowledge and conscious decision making, wherein stressful situations are recognized, the relevant responses are identified (e.g. the technique of writing diary entries/notes), and the process of conscious decision making takes place (e.g. the FILÉ four questions technique). The second topic introduces stress relief skills (e.g. thought stopping, distraction, recognition of cognitive biases, reframing negative thoughts, relaxation and meditation techniques). The third topic presents the action skills (e.g. problem-solving and assertive communication, formulation of requests, saying no). Topic number four set out to pass on relationship-building skills 
(e.g. receptive listening, effective speaking, empathy, emotional intelligence, positive manifestations). The program aims to break down the complex, persistent problems into smaller subproblems for manageability considerations and facilitate resolution attempts. Participants are given home assignments at the end of each session, their accomplishments being discussed in the following one (Stauder, 2016).

\begin{tabular}{|c|c|c|c|c|}
\hline Authors & Sample & Objective & $\begin{array}{c}\text { Presentation of the } \\
\text { behavioral medicine } \\
\text { program; topics } \\
\text { involved } \\
\end{array}$ & Results \\
\hline $\begin{array}{l}\text { Gidron, } \\
\text { Davidson, } \\
\text { and Bata } \\
(1999)\end{array}$ & $\begin{array}{l}22 \text { male } \\
\text { cardiac } \\
\text { patients with } \\
\text { a history of } \\
\text { myocardial } \\
\text { infarction } \\
\text { were } \\
\text { examined. }\end{array}$ & $\begin{array}{l}\text { Through the } \\
\text { intervention, they } \\
\text { looked at hostility. } \\
\text { They sought to } \\
\text { improve patients' } \\
\text { physiological well- } \\
\text { being. }\end{array}$ & $\begin{array}{l}\text { Patients were divided } \\
\text { into two groups } \\
\text { (experimental and } \\
\text { control groups). } \\
\text { The experimental } \\
\text { group underwent } \\
\text { post-treatment for } \\
\text { two months while } \\
\text { group members were } \\
\text { continuously giving } \\
\text { feedback about } \\
\text { themselves. }\end{array}$ & $\begin{array}{l}\text { Patients' level of hostility decreased after post- } \\
\text { treatment }(\mathrm{M}=11.0) \text { and follow-up }(\mathrm{M}=10.3) \\
\text { compared to the control group }(\mathrm{M}=14.3, \mathrm{t}= \\
2.33, \mathrm{p}<.05, \text { and } \mathrm{M}=13.7, \mathrm{t}=2.80, \mathrm{p}<.05) . \\
\text { This change persisted during the follow-up } \\
\text { phase both in the experimental }(\mathrm{M}=2.9) \text { and } \\
\text { the control group }(\mathrm{M}=3.6, \mathrm{t}=2.80, \mathrm{p}<.05) . \\
\text { Patients' blood pressure in the experimental } \\
\text { group decreased during post-treatment }(\mathrm{M}= \\
85.2) \text { when compared to the control group }(\mathrm{M} \\
=94.4, \mathrm{t}=1.8, \mathrm{p}<.08) \text {. } \\
\text { These changes could be observed also during } \\
\text { the follow-up period in the experimental }(\mathrm{M}= \\
81.8) \text { and the control group }(\mathrm{M}=95.0, \mathrm{t}=3.2, \\
\mathrm{p}<.05) \text { alike. } \\
\text { In addition, researchers have shown a } \\
\text { correlation between blood pressure and } \\
\text { changes in hostility. During pre- and post- } \\
\text { treatment, changes in hostility indicated a } \\
\text { positive and significant relationship with } \\
\text { changes in the blood pressure from post- } \\
\text { treatment to follow-up ( } \mathrm{r}=.49, \mathrm{p}<.05) .\end{array}$ \\
\hline $\begin{array}{l}\text { Bishop, } \\
\text { Kaur, Tan, } \\
\text { Chua, } \\
\text { Liew, and } \\
\text { Mak (2005) }\end{array}$ & $\begin{array}{l}\text { Male patients } \\
\text { younger than } \\
70 \text { years of } \\
\text { age who had } \\
\text { previously } \\
\text { undergone } \\
\text { coronary } \\
\text { bypass } \\
\text { surgery were } \\
\text { examined. }\end{array}$ & $\begin{array}{l}\text { The relationships } \\
\text { between CVR } \\
\text { stress (differences } \\
\text { in cardiac function } \\
\text { and blood pressure } \\
\text { during sleeping and } \\
\text { the presence of an } \\
\text { external stressor) and } \\
\text { stroke and between } \\
\text { stress management } \\
\text { and the education } \\
\text { program were placed } \\
\text { under examination. } \\
\text { Patients were } \\
\text { followed up for ten } \\
\text { months. }\end{array}$ & $\begin{array}{l}\text { Topics that came up } \\
\text { included emotional } \\
\text { distress, psychosocial } \\
\text { skills development, } \\
\text { hostility, and stress. } \\
\text { They worked } \\
\text { with two groups, } \\
\text { intervention being } \\
\text { performed with one } \\
\text { of them, whereas } \\
\text { the other was only } \\
\text { provided with } \\
\text { information. }\end{array}$ & $\begin{array}{l}\text { No significant difference was found between } \\
\text { the two groups. As a result of the programme, } \\
\text { depression (pre-test: } 11.1 \pm 1.69, \text { post-test: } \\
7.2 \pm 1.63 ; \mathrm{p}<.05, \mathrm{~d}=0.38 \text { ) and perceived } \\
\text { stress (pre-test: } 22.1 \pm 1.23 \text {, post-test: } 19.3 \\
\pm 1.14 ; \mathrm{p}<.05, \mathrm{~d}=0.37 \text { ) decreased and life } \\
\text { satisfaction increased (pre-test: } 23.8 \pm 1.15, \\
\text { post-test: } 27.7 \pm 0.81 ; \mathrm{p}<.01, \mathrm{~d}=0.59 \text { ), while } \\
\text { anger as a personality trait decreased (pre-test: } \\
21.2 \pm 0.87 \text {, follow-up: } 17.4 \pm 0.80 ; \mathrm{p}<.001, \\
\mathrm{~d}=0.82 \text { ) among members of the intervention } \\
\text { group during the follow-up phase. } \\
\text { Further, both blood pressure (pre-test: } 122.3 \\
\pm 3.73, \text { post-test: } 118.7 \pm 2.37 ; \mathrm{p}<.001, \mathrm{~d}= \\
1.05 \text { ) and heart rate (pre-test: } 72.1 \pm 2.20, \text { post- } \\
\text { test: } 65.2 \pm 1.75 ; \mathrm{p}<.001, \mathrm{~d}=0.58 \text { ) dropped } \\
\text { in the intervention group. Finally, cholesterol } \\
\text { levels, body weight, and long-term mortality } \\
\text { rate decreased in these groups. }\end{array}$ \\
\hline
\end{tabular}




\begin{tabular}{|c|c|c|c|c|}
\hline Authors & Sample & Objective & $\begin{array}{c}\text { Presentation of the } \\
\text { behavioral medicine } \\
\text { program; topics } \\
\text { involved }\end{array}$ & Results \\
\hline $\begin{array}{l}\text { Kirby, } \\
\text { Williams, } \\
\text { V. P., } \\
\text { Hocking, } \\
\text { Lane, and } \\
\text { Williams, } \\
\text { R. B. } \\
\text { (2006) }\end{array}$ & $\begin{array}{l}196 \text { working } \\
\text { people aged } \\
\text { over } 18 \\
\text { years were } \\
\text { examined, } \\
\text { who had } \\
\text { reported } \\
\text { increased } \\
\text { psychosocial } \\
\text { distress but } \\
\text { did not need } \\
\text { psychiatric } \\
\text { treatment. }\end{array}$ & $\begin{array}{l}\text { The long-term } \\
\text { efficiency of the } \\
\text { self-help video } \\
\text { version of the } \\
\text { Williams LifeSkills } \\
\text { Programme was } \\
\text { investigated } \\
\text { concerning } \\
\text { psychological risk- } \\
\text { taking with the } \\
\text { involvement of } \\
\text { healthy individuals. }\end{array}$ & $\begin{array}{l}\text { Topics that came } \\
\text { up included } \\
\text { psychological } \\
\text { risk factors, stress } \\
\text { management, } \\
\text { cognitive-behavioral } \\
\text { therapy, and life } \\
\text { skills. } \\
\text { Three experimental } \\
\text { and one control } \\
\text { group were used. } \\
\text { Psychological risk } \\
\text { factors were assessed } \\
\text { at first ten days and } \\
\text { then two months and } \\
\text { six months following } \\
\text { the training. }\end{array}$ & $\begin{array}{l}\text { There was a significant improvement after ten } \\
\text { days in terms of trait anxiety }(\mathrm{F}=4.70[3], \mathrm{p}= \\
.0039) \text { and perceived stress }(\mathrm{F}=2.99[3], \mathrm{p}= \\
.0340) \text { as compared to the control group. } \\
\text { This improvement could be observed in the } \\
\mathrm{WV} \text { (workshop-video) and the VO (video) } \\
\text { groups in the short term. In contrast, in } \\
\text { the long term, this change was reflected in } \\
\text { decreased levels of trait anxiety detected again } \\
\text { in the } W V(\mathrm{~F}=4.72[3], \mathrm{p}=.0034) \text { and } V O(\mathrm{~F} \\
=2.86[3], \mathrm{p}=.0385) \text { groups. However, long- } \\
\text { term changes concerning the stress-reducing } \\
\text { effects of the program persisted ( } \mathrm{F}=2.95[3], \mathrm{p} \\
=.0342) \text { in the } W V \text { group alone. Unlike in the } \\
\text { control group, this change could be measured } \\
\text { even six months following the intervention. }\end{array}$ \\
\hline $\begin{array}{l}\text { Williams, } \\
\text { V. P., } \\
\text { Brenner, } \\
\text { Helms, and } \\
\text { Williams, } \\
\text { R. B. } \\
(2009)\end{array}$ & $\begin{array}{l}110 \text { working } \\
\text { people were } \\
\text { examined } \\
\text { who had } \\
\text { reported } \\
\text { increased } \\
\text { psychosocial } \\
\text { distress. }\end{array}$ & $\begin{array}{l}\text { The effectiveness } \\
\text { of the Williams } \\
\text { LifeSkills } \\
\text { Programme } \\
\text { was measured } \\
\text { considering anxiety, } \\
\text { depression, hostility, } \\
\text { and social support. } \\
\text { They examined } \\
\text { how the coping } \\
\text { skills development } \\
\text { program reduces } \\
\text { mental disorders } \\
\text { among working } \\
\text { people exposed to } \\
\text { increased stress. Its } \\
\text { effectiveness was } \\
\text { compared to results } \\
\text { obtained with cardiac } \\
\text { patients. }\end{array}$ & \begin{tabular}{|l|} 
Important topics \\
included behavioral \\
intervention, \\
practicing coping \\
skills, efficiency, and \\
workplace stress. \\
A two-day training \\
was conducted, \\
and data on the two \\
groups were obtained \\
using feedback \\
questionnaires. \\
\end{tabular} & $\begin{array}{l}\text { The program proved to be successful with } \\
\text { individuals exposed to workplace stress, just } \\
\text { as among cardiac patients. The following } \\
\text { items showed a decrease: depression }(30 \%) \text {, } \\
\text { hostility }(20 \%) \text {, state anxiety }(12 \%) \text {, and trait } \\
\text { anxiety }(10 \%) \text {. This change was not affected } \\
\text { by either ethnic background or gender, or } \\
\text { the type of workplace. Job-status indicated } \\
\text { a significant relationship only with the } \\
\text { dimension of social support }(F(1,68)=4.30, \\
\mathrm{p}=0.04) \text {. These changes persisted even six } \\
\text { months after the intervention. There was no } \\
\text { substantial difference between men and women } \\
\text { in the dimension of hostility, but the groups of } \\
\text { both men ( } \mathrm{p}<.0001) \text { and women }(\mathrm{p}=0.038) \\
\text { showed a significant decrease in hostility as a } \\
\text { result of the program. }\end{array}$ \\
\hline $\begin{array}{l}\text { Williams, } \\
\text { V. P., } \\
\text { Bishop- } \\
\text { Fitzpatrick, } \\
\text { Lane, } \\
\text { Gwyther, } \\
\text { Ballard, } \\
\text { and Vendit- } \\
\text { telli (2010) }\end{array}$ & $\begin{array}{l}116 \text { persons } \\
\text { treating } \\
\text { Alzheimer's } \\
\text { patients were } \\
\text { examined. }\end{array}$ & $\begin{array}{l}\text { It was examined } \\
\text { whether the } \\
\text { video-based skills } \\
\text { development } \\
\text { program reduces the } \\
\text { psychological and } \\
\text { distress indicators in } \\
\text { these persons. }\end{array}$ & \begin{tabular}{|l|} 
Subjects addressed \\
were Alzheimer's \\
disease, coping skills \\
training, and \\
stress associated with \\
the nursing work. \\
The Williams \\
LifeSkills video
\end{tabular} & $\begin{array}{l}\text { A comparison between the experimental } \\
\text { and the control group revealed significant } \\
\text { improvement with respect to depressive } \\
\text { symptoms }[\mathrm{F}(1,101)=4.19, \mathrm{p}=.04] \text {, trait } \\
\text { anxiety }[\mathrm{F}(1,101)=3.17, \mathrm{p}=.08] \text {, perceived } \\
\text { stress }[\mathrm{F}(1,101)=4.08, \mathrm{p}<.05] \text {, and blood } \\
\text { pressure }[\mathrm{F}(1,101)=3.96, \mathrm{p}<.05] \text {. }\end{array}$ \\
\hline
\end{tabular}




\begin{tabular}{|c|c|c|c|c|}
\hline Authors & Sample & Objective & $\begin{array}{l}\text { Presentation of the } \\
\text { behavioral medicine } \\
\text { program; topics } \\
\text { involved }\end{array}$ & Results \\
\hline & & & $\begin{array}{l}\text { program was used. } \\
\text { Participants were } \\
\text { called on the } \\
\text { phone every week } \\
\text { for five weeks, } \\
\text { providing them with } \\
\text { instructions. } \\
\text { Then, after } \\
\text { seven weeks, the } \\
\text { questionnaires } \\
\text { previously filled in } \\
\text { were evaluated. } \\
\text { After three and six } \\
\text { months, follow-up } \\
\text { surveys were } \\
\text { performed. }\end{array}$ & \\
\hline $\begin{array}{l}\text { Stauder, } \\
\text { Balog, } \\
\text { Kovács, } \\
\text { and } \\
\text { Susánszky } \\
(2016)\end{array}$ & $\begin{array}{l}\text { Nearly } 4,000 \\
\text { individuals } \\
\text { participated } \\
\text { in the WÉK } \\
\text { program } \\
\text { nationwide } \\
\text { until the year } \\
2015 \text {. There } \\
\text { is a wide } \\
\text { range of par- } \\
\text { ticipants con- } \\
\text { sidering that } \\
\text { it focuses on } \\
\text { stress man- } \\
\text { agement and } \\
\text { efficient com- } \\
\text { munication. } \\
\text { An additional } \\
200 \text { domestic } \\
\text { professionals } \\
\text { have com- } \\
\text { pleted the } \\
\text { facilitator } \\
\text { training. }\end{array}$ & $\begin{array}{l}\text { To exert a positive } \\
\text { influence on the } \\
\text { quality of life and } \\
\text { state of health by } \\
\text { eliminating hostility, } \\
\text { lack of social } \\
\text { support, pessimism, } \\
\text { persistent physical } \\
\text { and psychological } \\
\text { stress, and } \\
\text { maladaptive coping } \\
\text { methods. }\end{array}$ & $\begin{array}{l}\text { Its primary method } \\
\text { is psychoeducation. } \\
\text { It touches upon } \\
\text { subjects such } \\
\text { as stress, stress } \\
\text { management, } \\
\text { behavioral medicine, } \\
\text { and coping. Four } \\
\text { major topics are } \\
\text { covered, wherein } \\
\text { it develops } \\
\text { fundamental coping } \\
\text { skills (e.g. self- } \\
\text { knowledge and } \\
\text { conscious decision } \\
\text { making, emotion- } \\
\text { focused, problem- } \\
\text { focused, and support- } \\
\text { seeking coping } \\
\text { strategies). }\end{array}$ & $\begin{array}{l}\text { The efficiency of the WÉK basic training } \\
\text { was reflected on several levels. According to } \\
\text { participants' subjective satisfaction indicators, } \\
\text { the average value of satisfaction was } 4.2 \text { on } \\
\text { a five-point scale (1-5), while } 80 \% \text { of them } \\
\text { would recommend the program for their } \\
\text { acquaintances (Stauder, 2008). A survey- } \\
\text { based scientific study also corroborated the } \\
\text { efficiency of the training. Coping skills showed } \\
\text { improvement, and the levels of perceived } \\
\text { stress, anxiety and depression decreased, just } \\
\text { as subjective physical symptoms. Improved } \\
\text { coping abilities and reduced stress symptoms } \\
\text { could be observed even six months after the } \\
\text { training (Stauder, 2010). }\end{array}$ \\
\hline
\end{tabular}

Table 1. Research results of the Williams LifeSkills Programme's efficacy on the national and international arena 


\section{The objective and purpose of the inter- vention}

The intervention's general purpose is to facilitate cancer patients' mental health in tertiary prevention. We were looking for connections between body image and attitude towards the disease. In addition to increasing their self-esteem, we aimed to change their coping skills on the cognitive level.

\section{Participants of the intervention}

A focus group is a self-help group made up of 11 persons - cancer survivor patients who are making mental and physical efforts to cope with the adverse effects of the disease. One person could be present at the first meeting only, so $\mathrm{s} / \mathrm{he}$ is not included in the evaluation. The group had a mixed composition in terms of gender, male and female participants being equally present. The patients' age group ranged between 44 and 65 years, with an average age of 56.54 .

\section{Hypotheses}

Three specific hypotheses were formulated in connection with the correlation between the individual variables and the efficiency of the intervention:

1. By the end of the Williams LifeSkills development intervention, participants will be able to cope with their problems more efficiently.

2. Changes in the group members' body image will be directly proportional to changes in their self-esteem:

- Their improved body image will accompany the positive changes in their self-esteem, while low body image will entail low self-esteem.

- Persons who will have developed a more positive body image or self-esteem by the end of the Williams LifeSkills intervention will be able to cope with their problems more efficiently, thereby also adopting more efficient coping strategies in facing the disease.

- Persons who will have a lower body image and self-esteem by the end of the Williams LifeSkills intervention will adopt less efficient methods in coping with their problems, thereby also adopting less efficient coping strategies in facing the disease.

\section{Methods and tools}

The efficiency of the Williams LifeSkills development sessions was measured via pre- and posttest using paired sample t-test.

The BSQ - Body Shape Questionnaire (Czeglédi, 2012) was adopted in assessing participants' body image. We used the Rosenberg SelfEsteem Scale (Sallay, 2014) to examine their attitude to themselves and the Tennessee Self-Concept Scale's (Czeglédi-Urbán-Csizmadia, 2011) subscale addressing body image to measure satisfaction with various areas of the body. Different body image illustrations were adopted to assess group members' actual body image compared to their body shape. Patients' attitude towards their disease was evaluated using the Ways of Coping Questionnaire (Rózsa, 2008) - more specifically, the revised and abridged version of the Conflict Management Questionnaire.

\section{Steps of the intervention}

On average, each session lasted 1.5-2 hours. Starting the group sessions was determined by the number of group members present depending on the total number. We met on six occasions altogether, twice per month from March through May. The meetings were held in Cluj-Napoca within the framework of a cancer self-help group.

The table included in the appendix consists of the topics and objectives of each meeting and the methods and tools used during the sessions (see Appendix 1).

Group sessions began with an initial round and ended with a closing round. During these two phases, they were given the opportunity to share their feelings upon arrival on the one hand and upon leaving on the other, also telling the group what they were taking with them.

\section{Results}

\section{Correlations between the variables}

Data obtained during the pre- and post-test suggested correlations between several variables. A correlation was found in ten persons, according to which: among the modes of coping, the increased value for 
problem analysis was accompanied by an increase in self-esteem or satisfaction with body areas and body image during the post-test. By contrast, a corresponding decrease contributed to decreased satisfaction with body areas and body image or self-esteem (see tables 2-4).

\begin{tabular}{lcccc}
\hline & $\boldsymbol{M}$ & $\boldsymbol{S D}$ & $\boldsymbol{t}(10)$ & $\boldsymbol{p}$ \\
\hline MMK_PE_post & 7.82 & \multirow{2}{*}{23.74} & $p<.000$ \\
\hline Rosenberg_post & 30.64 & 3.85 & & \\
\hline
\end{tabular}

Table 2. Correlations between problem analysis and self-esteem during the post-test

Note: MMK_PE_post - Ways of Coping Questionnaire - Problem analysis

\begin{tabular}{lcccc}
\hline & $\boldsymbol{M}$ & $\boldsymbol{S D}$ & $\boldsymbol{t}(10)$ & $\boldsymbol{p}$ \\
\hline MMK_PE_post & 7.82 & 2.23 & & \multirow{2}{*}{$9.67 p<.000$} \\
\hline TTE_post & 25.91 & 7.02 & & \\
\hline
\end{tabular}

Table 3. Correlations between problem analysis and satisfaction with body areas during the post-test

Note: TTE_post - Body Areas Satisfaction Scale

\begin{tabular}{lcccc}
\hline & $\boldsymbol{M}$ & $\boldsymbol{S D}$ & $\boldsymbol{t}(\mathbf{1 0 )}$ & $\boldsymbol{p}$ \\
\hline MMK_PE_post & 7.82 & & \multirow{2}{*}{-6.65} & $p<.000$ \\
\hline BSQ_post & 33.64 & 2.23 & 11.68 & \\
\hline
\end{tabular}

Table 4. Correlations between problem analysis and body image during the post-test (BSQ)

Note: BSQ post - Body Shape Questionnaire image influences the development of the strategy of

Therefore, we can conclude that problem analysis as a way of coping appears in individuals with a more positive self-image or body image. Problem analysis is also accompanied by a certain level of sense of competence. Hence, self-image or body problem analysis in individuals. A further examination of the results brings to light more correlations concerning the ways of coping. The subscale of the cognitive restructuring of the modes of coping shows a strong, positive relationship with the examined subjects' body image (see Table 5).

\begin{tabular}{lcccc}
\hline & $\boldsymbol{M}$ & $\boldsymbol{S D}$ & $\boldsymbol{t}(10)$ & $\boldsymbol{p}$ \\
\hline MMK_KA_post & 16.36 & 1.96 & \multirow{2}{*}{-4.57} & $p<.001$ \\
\hline BSQ_post & 33.64 & 11.68 & & \multirow{2}{*}{. } \\
\hline
\end{tabular}

Table 5. Correlations between cognitive restructuring and body image during the post-test

Note: MMK KA post - Ways of Coping Questionnaire - Cognitive Restructuring

Participants indicating an increased cognitive restructuring also showed a more positive body image. This correlation is also confirmed by the results of the paired sample t-test. We take the view that this correlation stems from the sense of competence present during cognitive restructuring. This sense of competence cannot do without a high level of self-acceptance reflected in the body image. Therefore, an increased level of cognitive restructuring was accompanied by an improved body image as well. These correlations came into view again in the dimension of self-esteem. The modes of cognitive restructuring accompanied participants' self-esteem (see Table 6), stress reduction (see Table 7), and passive coping (see Table 8) in direct or indirect proportion to them. 
Research article

\begin{tabular}{lcccc}
\hline & $\boldsymbol{M}$ & $\boldsymbol{S D}$ & $\boldsymbol{t}(10)$ & $\boldsymbol{p}$ \\
\hline Ros_post & 30.64 & 3.85 & \multirow{2}{*}{13.02} & $p<.000$ \\
\hline MMK_KA_post & 16.36 & 1.96 & & \\
\hline
\end{tabular}

Table 6. Correlations between self-esteem and cognitive restructuring during the post-test

Note: Ros_post - Rosenberg Self-Esteem Scale thus more prone to adopt the coping strategy of cogIndividuals with appropriate self-esteem are nitive restructuring in problem situations.

\begin{tabular}{lcccc}
\hline & $\boldsymbol{M}$ & $\boldsymbol{S D}$ & $\boldsymbol{t}(10)$ & $\boldsymbol{p}$ \\
\hline Ros_post & 30,64 & 3,85 & 25.22 & $p<.000$ \\
\hline MMK_FR_post & 1.36 & 1.43 & & \\
\hline
\end{tabular}

Table 7. Correlations between self-esteem and stress reduction during the post-test

Note: MMK_FR_post - Ways of Coping results yielded constant values for stress reduction as Questionnaire - Stress reduction well. Consequently, self-esteem indicates a correla-

This result reveals that patients with a decreased self-esteem also show a low-stress reduction. However, individuals showing no change in the tion with individuals' potential to act in a particular situation, even if that means channeling their stress into addictions or taking it out on others.

\begin{tabular}{lcccc}
\hline & $\boldsymbol{M}$ & $\boldsymbol{S D}$ & $\boldsymbol{t}(10)$ & $\boldsymbol{p}$ \\
\hline Ros_post & 30.64 & 3.85 & 20.54 & $p<.000$ \\
\hline MMK_PM_post & 3.64 & 0.92 & & \\
\hline
\end{tabular}

Table 8. Correlations between self-esteem and passive coping during the post-test

Note: MMK_PM_post - Ways of Coping Questionnaire - Passive coping

The passive coping style remained unchanged for most of the group members during the pre- and post-test.
- A person showing reduced values for passive coping style produced visibly increased values for self-esteem.

In addition, self-esteem and satisfaction with body areas indicated a significant relationship with each other (see Table 9).

\begin{tabular}{lcccc}
\hline & $\boldsymbol{M}$ & $\boldsymbol{S D}$ & $\boldsymbol{t}(10)$ & $\boldsymbol{p}$ \\
\hline Ros_post & 30,64 & 3,85 & \multirow{2}{*}{3,27} & \multirow{2}{*}{$p<.008$} \\
\hline TTE_post & 25,91 & 7,02 & & \\
\hline
\end{tabular}

Table 9. Correlations between self-esteem and satisfaction with body areas during the post-test

Note: TTE_post - Body Areas Satisfaction Scale

Self-esteem is thus directly proportional to satisfaction with body areas, a fact also confirmed by the level of significance demonstrated using t-test. This lets us conclude that our self-esteem comprises our attitude towards our outward physical appearance.

\section{Examining the effectiveness of the intervention}

Effectiveness was examined by comparing pre-test and post-test results using paired sample

t-test. Analyzing the attitude towards the disease was performed following the four dimensions of coping styles. The dimension of cognitive restructuring showed a significant change (see Table 10), non-significant changes could be observed in the measurement of stress reduction (see Table 11), and a significant decrease was registered among the participants. Both pre-test and post-test indicated significant results in this area, obtained through paired sample t-test. 
Journal of School and University Medicine

\begin{tabular}{lcccc}
\hline & $\boldsymbol{M}$ & $\boldsymbol{S D}$ & $\boldsymbol{t}(10)$ & $\boldsymbol{p}$ \\
\hline Pre-test & 9.27 & 3.69 & -5.12 & $p<.000$ \\
\hline Post-test & 16.36 & 1.96 & & \\
\hline
\end{tabular}

Table 10. Comparison of pre-test and post-test results in the dimension of cognitive restructuring

Stress reduction decreased, and cognitive restructuring showed a spectacular increase in the majority of the group members following the post-test. The average scores obtained during the pre-test and the post-test were $9.27(\mathrm{SD}=3.69)$ and $16.36(\mathrm{SD}$ $=1.96$ ), respectively. In our opinion, the results demonstrate the effectiveness of the mental health intervention among the participants. By the end of the interventions, group members could think more efficiently about their existing issues. They showed more awareness in resolving their difficulties, strategically reframing their current situation.

Individuals who generally did not resort to stress reduction scored low on self-esteem or satisfaction with body areas. Although not significantly, the results of the paired sample t-test revealed a decrease during the pre- and post-test $(\mathrm{p}<.076, \mathrm{t}(10)=1.98)$ concerning the application of stress-reduction-based coping strategies (see Table 11). The average scores of the pre-test and post-test were $2.36(\mathrm{SD}=2.50)$ and $1.36(\mathrm{SD}=1.43)$ respectively.

\begin{tabular}{lcccc}
\hline & $\boldsymbol{M}$ & $\boldsymbol{S D}$ & $\boldsymbol{t}(10)$ & $\boldsymbol{p}$ \\
\hline Pre-test & 2.36 & 2.50 & & \\
\hline Post-test & 1.36 & 1.43 & 1.98 & $p<.076$ \\
\hline
\end{tabular}

Table 11. Comparison of pre-test and post-test results as a function of stress reduction

Though not significantly, these results confirm the more efficient, cognitive-level changes in problem-solving. This way, stress reduction as a coping style with a negative effect is significantly pushed into the background, and the method of cognitive restructuring takes its place. The participants' problem analysis scores also revealed a slight upward trend during the post-test, but this difference cannot be regarded as significant. The average points produced at the time of the pre-test and post-test were $7.55(\mathrm{SD}=2.34)$ and $7.82(\mathrm{SD}=2.23, \mathrm{p}<.669, \mathrm{t}(10)=0.44)$ respectively. When analyzing body image - although no significant correlation could be observed between pre-test and post-test $(\mathrm{p}<.476, \mathrm{t}(10)=0.74)-$, participants' average score indicated a positive decrease during post-test as compared to pre-test values $(\mathrm{M}=35)$. We believe this means that they became, even though to a small extent, more accepting of their appearance. The same can be observed in the dimension of self-esteem. The average scores for the pre-test and post-test were $30.18(\mathrm{SD}=4.64)$ and $30.64(\mathrm{SD}=3.58, \mathrm{p}<.679, \mathrm{t}$ $(10)=0.43)$ respectively. Considering the dimension of satisfaction with body areas, the average scores of participants expressed a slight decrease during the pre-test $(\mathrm{M}=26.55, \mathrm{SD}=5.94)$ and the post-test $(\mathrm{M}$
$=25.91, \mathrm{SD}=7.02, \mathrm{p}<.703, \mathrm{t}(10)=0.39)$. This result suggests in our view that patients' assessment of their attitude towards their body areas takes place on a more conscious level, which was not the case in the initial stage.

We used body image illustrations to investigate participants' realistic sense of body image before and after the intervention. We investigated whether any changes occurred in terms of how they perceived their outward appearance in the world and also verified how this image corresponded to reality. Most of the subjects manifested no changes in how they saw themselves, and this image compared to reality, meaning that they had a realistic sense of body image. Only three individuals exhibited slight changes. We presume this change reflects a certain instability in how they view themselves, and we tend to believe that this is somewhere between desire and reality and between how they wish to be like and how they are. Therefore, desires are mixed with reality. According to our observations, changes occurred in individuals who, due to their personality, showed greater sensitivity to the outside world's opinion, thus being more dependent on others' expectations. 


\section{Conclusions}

During the six sessions of the intervention conducted in the self-help group of patients combating the adverse effects of cancer, some changes could be observed in various areas. Accordingly, participants' problem-solving style showed changes in two areas: group members favored the coping style of cognitive restructuring. In contrast, the stress reduction coping strategy showed a significant downward trend compared to the initial state. This way, participants managed to change their attitude and approach to the problem situation by reframing their mindset. First of all, they no longer tried to reduce the tensions accumulated in the problem situations. Still, they sought a solution to the problem itself, taking a different perspective on their situation. In this regard, our first hypothesis has been confirmed, according to which participants will be able to cope with their current issues more efficiently by the end of the intervention. Therefore, the intervention proved to be successful. These results are also supported by the findings of Dombeck and Wells-Moran (2006). They underline the greater efficiency of problem-focused coping than stress reduction and emotion-focused strategies (Tasnádi-Dégi, 2016). The dimension of problem analysis also indicated an increase, although not significant, compared to the pre-test. We believe this change also attests to the more efficient transformation of the coping style (Lazarus-Folkman, 1984). The observed changes reinforce the conclusions drawn from the national and international research results of the WÉK Programme. In the intervention course, the efficiency of group members' coping skills showed improvement (Stauder, 2016). In the meantime, their perceived level of stress decreased significantly, just as in the case of the Williams LifeSkills prevention programs (see Williams, Brenner, Helms, and Williams, 2009).

Participants' acceptance of their own body image and their self-esteem indicated a positive increase during the intervention program, though not a significant one. This result suggests that they have become more accepting of and more confident about their outward appearance only to a slight degree.

As mentioned in the literature, changes in body image impact self-esteem as well (Kende, 2002) hence, these two factors are consistent with each other
(Cash, 2004). This observation has been reinforced by our mental health intervention results, which indicated a significant relationship between self-esteem and satisfaction with body areas. Our second hypothesis has also been confirmed, claiming that changes in the participants' body image will be directly proportional to changes in their self-esteem.

Results obtained from the intervention revealed further interesting connections in these areas. The coping method of cognitive restructuring showed a significant relationship with participants' body image, while problem analysis correlated with self-esteem and satisfaction with body areas. These results support the third hypothesis stating that persons who will have developed a more positive body image or self-esteem by the end of the Williams LifeSkills intervention will be able to cope with their problems more efficiently, thereby also adopting more efficient coping strategies facing the disease. Persons who will have a lower body image and self-esteem will adopt less efficient methods in coping with their problems, thereby also adopting less efficient coping strategies in facing the disease. We believe that the connections discussed above are clear reflections of observations found in the literature that changes in the body image and self-esteem may be greatly dependent on both patients' mentality and coping skills (Csabai, 2009). In addition, it has also been confirmed that changes in body image and self-esteem are not contingent only upon the extent of the changes in the body (Csabai, 2009). However, the reverse of this correlation is also true in the course of the physical changes occurring due to the disease, backed up by research mentioned in the literature (Pongrácz, 2014: 130). Correlations of this nature emerged in other areas of coping strategies as well. Stress reduction showed a directly proportional relationship with changes in self-esteem. Hence, as self-esteem increased, stress reduction also increased, while its decrease caused a corresponding shift in stress reduction. We believe this lies in the fact that group members' self-esteem incorporated their sense of self-efficacy. This phenomenon was reflected in the success of adopting stress reduction strategies, just as in cognitive-level coping styles. This is also reinforced by the reverse relationship of passive coping style concerning changes in self-esteem. Therefore, a decrease in self-esteem affects passive coping, 
where group members expect to find the solution to their problems from the circumstances and not from themselves. The importance of developing a sense of competence is emphasized by the literature (based on Bandura, 1982 and Horti, 2017).

The majority of the participants had a realistic body image, and there was no change in the initial and final results. Still, a difference between the two results could be noticed in the case of three patients. The last survey, however, yielded more realistic results concerning body image illustrations.

Group members' feedbacks underpin the efficiency of the WÉK Programme and the mental health intervention concerning stress management and problem-solving (Kirby, 2006). According to their report, deficiencies in assertiveness skills gave rise to the most significant problems. In the future, the application of these skills will receive much more emphasis. Patients acquired considerable psychoeducational knowledge when dealing with the negative consequences of avoiding confrontation with their problems. They claimed that the technique of movement and dance therapy was closely linked to relieving their tensions and achieving a positive awareness of life, a statement also sustained by research mentioned in the literature (Kállai, 2013: 275). However, it is possible that the improvement noticed in their self-esteem and body image can be attributed to this movement therapy and the dance moves practiced in front of the mirror. This assumption is supported by several previous research studies already mentioned in the literature (based on Sági, 2012; Hausenblas, 2006, and Depcik, 2004).

Personal progress observed in participants also speaks for the efficiency of the adopted intervention program. The hostility of some of the patients significantly dissolved while they became more accepting of the circumstances. This correlation is supported by Gidron, Davidson, and Bata's (1999) research results obtained in the dimension of hostility examined among male cardiac patients with a history of myocardial infarction. We assume, however, that this change could be caused by the WÉK Programme just as by the efficiency of the confrontation and interpretation tool (Stock, 1981) - reinforced by the literature - against transference (Dorothy-Morton, 1981 - qtd. in Rudas, 1990). Based on our observations, experiencing the feeling of social support through physical contact contributed to positive changes in the body image of some patients. This also added to the fact that some people became more accepting of their physical appearance. Likewise, a calm atmosphere and freedom of expression significantly reduced their initial frustrations. We believe that the reason for the positive changes we could observe is to be looked for in group interactions, an assumption supported by the literature as well (based on Dégi, 2010; Rudas, 1990, and Kopp, 2001).

We confirmed the hypotheses that the literature supported among patients struggling with cancer during the mental health intervention. Due to stigmatization and isolation, individuals diagnosed with cancer often become introverted, making it increasingly more difficult for them to seek external assistance (Kurimay, 2004). Group members were usually suffering because their environment did not understand them or downplayed the severity of their disease (Csabai, 2009). They reported this at the very first session. When the diagnosis was communicated to them, they experienced such intense anxiety that some resorted to the defense mechanism of denial. For some of them, however, this became a prolonged condition persisting for extended periods. This can be considered a pathological process preventing the person from developing healthier coping processes (see Lazarus, 1983; Meyerowitz, 1983). The short period of this regressive mental state and fear from the adverse effects of the treatments could be noticed in several group members (based on Pongrácz, 2014; Riskó, 1999).

As a consequence, one of the patients turned to alternative healing methods instead of undergoing treatments from the very beginning (LazarusFolkman, 1984; Meyerowitz, 1983). At the fifth meeting, several participants reported phantom pain after surgical procedures had been performed upon them. However, these could be indicators of post-surgery anxiety, decrease in self-esteem, and maladaptation (based on Panyi-Lábadi, 2015; Kende, 2002). We, therefore, believe that the group sessions had a beneficial effect on the positive changes in participants' adaptability, relieving their stress, and increasing their self-esteem. 
Overall, it may be said that this intervention program was helpful for the mental health growth of the entire group. Patients struggling with the consequences of the disease need to share their experiences in the group where they are accepted and understood by like-minded fellow sufferers. They need to refresh or acquire stress reduction and problem-solving techniques to manage the processes of coping with the disease daily. This is why the program proved highly applicable and valuable among healthy people and various conditions.

\section{Limits for the intervention}

We see time constraints as one of the significant shortcomings in the efficiency of the intervention program. When sharing their stories, such profound topics, ideas were revealed whose discussion required more time. The experiences we had in the group indicate that these discussions, in particular, facilitate mental health changes occurring at the individual level. In addition, it would take a lot more sessions to expand on each step of the WÉK Programme more thoroughly. Three-four occasions are not sufficient for the acquisition of knowledge at a deeper level. We hardly had enough time to discuss the importance of applying social skills. Therefore, we consider that it would be more appropriate to allow more time for conducting such programs in the future.

The lack of tools was another limitation in our view. Given that we did not have the opportunity to take part in the group leader training course of the WÉK Programme, we did not have the necessary materials that do not merely outline but also illustrate the possible solutions to problem situations through the use of everyday examples that can be viewed and listened to. Due to the experiential elements of learning, however, the application possibility of the program package could have yielded much higher efficiency in the group. As a result of the small number of participants, the positive changes measured in self-esteem and body image dimensions are not significant. On that account, it would be worth conducting this intervention program with larger sample size.

The measurement tools we adopted may have detracted from the validity of the results. The Ways of Coping Questionnaire measured only adaptation to the problem situation at hand, including instructions and statements formulated in the past tense. Correspondingly, group members examined their reactions observed upon diagnosing their condition and not the coping processes adopted in their present state. We, therefore, consider that the results obtained in the different areas on coping did not measure the time elapsed since the beginning of the intervention, but the time passed since the communication of the diagnosis up until the last meeting of the mental health intervention. Hence, these results are not due to the WÉK intervention alone but to group members' prior positive relaxation experiences. A more reliable investigation of the realistic sense of body image would call for larger sample size and more goal-oriented tools.

In our view, the more extensive application of the Williams LifeSkills Programme is highly essential. Those suffering from the disease's consequences need cognitive-level assistance in problem-solving and stress reduction, just as healthy individuals are. The efficiency of coping strategies may render cancer a controllable experience, but it can reduce various mental health risks. We all need to transform our thoughts, which could facilitate better adaptation to difficult situations. Mental health interventions in cancer communities do not merely provide support to patients but give individuals stigmatized by the disease a sense of competence to help them rebuild their lives.

\section{Acknowledgement}

This work was supported by a grant of the Ministry of Research, Innovation and Digitization, CNCS/CCCDI - UEFISCDI, project number PN-IIIP1-1.1-TE-2019-0097, within PNCDI III.

\section{References}

Bandura, A. (1982). Self-efficiency mechanism in human agency. American Psychologist 37: 2, 122-147.

Béres A., Czeglédi E., Babusa B. (2013). A testedzésfüggőség és a testkép vizsgálata fitneszedzést végző nők körében. Mentálhigiéné és Pszichoszomatika, 14, 92-93.

Bishop, G. D., Kaur, D., Tan, V.L., Chua, Y.L., Liew, S.M., \& Mak, K.H. (2005). Effects of a psychosocial skills training workshop on psychophysiological and psychosocial risk in patients undergoing coronary artery bypass grafting. American Heart Journal 150(3), 602-609. 
Carver, S. C. - Scheirer, M. F. (1998). Személyiségpszichológia. Budapest: Osiris Kiadó.

Cash, T. F., Pruzinsky, T. (2004). Body image. A handbook of theory, research and clinical practice. New York: Guilford Press.

Chan, C.K., Oldenburg, B., \& Viswanath, K. (2015). Advancing the Science of Dissemination and Implementation in Behavioral Medicine: Evidence and Progress. International Journal of Behavioral Medicine, 22(3), 277-282.

Cohen, S., Wills, T. A. (1985). Interpersonal Support Evaluation List (ISEL). In Cohen, S.-Wills, T. A.: Stress, Social Support, and the Buffering Hypothesis. Psychological Bulletin, 98, 310-357.

Czeglédi E., Csizmadia P., Urbán R. (2012). Testforma Kérdőiv - Röviditett változat. In A. G. Perczel F. D., Kérdöivek, becslöskálák a klinikai pszichológiában (pp.: 108-109). Budapest: Semmelweis Kiadó.

Czeglédi E., Urbán R., Csizmadia P. (2011). A testtel való elégedetlenség mérése és rizikótényezői. A Testforma Kérdőív rövidített formájának (Body Shape Questionnaire Short Form 14) hazai adaptációja . Psychiatria Hungarica, 26(4), 241-249.

Csabai M., Molnár P. (2009). Orvosi pszichológia és klinikai egészségpszichológia . Budapest: Medicina Könyvkiadó.

Dávid I., Fülöp. M., Pataky N., Rudas J. (2014. 12 2020.12.15). Stressz, megküzdés, versengés, konfliktusok. Forrás: geniusz_34_net: https://tehetseg.hu

Dégi L. Cs. (2010). A daganatos betegségek pszichoszociális elemzése . Kolozsvár: Presa Universitară Clujeană.

Depcik, E. \&. Williams, L. (2004). Weight training and body satisfaction of body-image-dis-turbed college women. Journal of Applied Sport Psychology, 16(3), 287-299.

Dombeck, M., Wells - Moran, J. (2020). Coping Strategies and Defense Mechanisms: Basic and Intermediate Defences. In Petkova, J.: Coping strategies against stress - A brief review. Trakia Journal of Sciences, 3, 274-278.

Gidron, Y., Davidson, K., \& Bata, I. (1999). The shortterm effects of a hostility-reduction intervention on male coronary heart disease patients. Health Psychol, 18(4), 416-420.

Hausenblas, H. A., \& Fallon, E. A. (2006). Relationship between exercise and body image: A meta-analysis. Psychology and Health, 21(1), 33-47.

Holmes, T., Rahe, R. H. (1967). The social readjustment rating scale. J. Psychosom. Res., 11: 2, 213-218.

Horti J., Riskó Á. (2017.05 2018.05.29). Onkopszichológia a gyakorlatban. 2. online kiadás, I. kötet. Budapest, Pest, Magyarország.

Kállai J., Szolcsányi T., Hegedűs G. (2013). A mükéz illúzió „hozzám tartozik, de nem az enyém”. Magyar Pszichológiai Szemle, 68:3, 457-474.

Kende A. (2002). Testazonosság és identitás. A különbözõ testfelfogások szerepe az önelfogadásban. In \&. F. M. Csabai, Test-beszédek (pp.: 61—84). Budapest: Animula.

Kirby, E. D., Williams, V. P., Hocking, M. C., Lane, J. D., \& Williams, R. B. (2006). Psychosocial benefits of three formats of a standardized behavioral stress management program. Psychosomatic Medicine, 68(6), 816-823.
Kopp M. ( 2001). Magatartástudományi ember környezeti rendszerszemléleti modell. In Buda B., Kopp M., Magatartástudományok (pp.: 23-46). Budapest: Medicina Kiadó.

Kopp M. \& Réthelyi J. (2004). Where psychology meets physiology: chronic stress and premature mortality - the CentralEastern European health paradox. Brain Research Bulletin, 62(5), 351-367.

Kopp M., Skrabski Á. (1995). Alkalmazott magatartástudomány. A megbirkózás egyéni és társadalmi stratégiái. Budapest: Corvinus Kiadó.

Kurimay, T. (2004). Családterápia és családkonzultáció. Európai távoktatási tankönyv. Budapest: Coincidencia Kiadó.

Lazarus, R. S. (1983). The costs and benefits of denial. In S. Bresnitz, Denial of stress (pp.: 1-30). New York: International Universities Press.

Lazarus, R. S., Folkman, S. (1984). Stress, Appraisals, and Coping. New York: Springer-Verlag.

Meyerowitz, B. E. (1983). Postmastectomy coping strategies and quality of life . Health Psychology, 2, 117-132.

Micskei, Orsolya, Deli, Tamás, Jakab, Attila, Bugán, (2014). A testkép és életminőség vizsgálata polycystás ovarium szindrómában. Orvosi Hetilap, 155: 27, 1071-1077.

Oláh A. (2005). Érzelmek, megküzdés és optimális élmény . Budapest: Trefort Kiadó.

Panyi L. K., Lábadi B. (2015). Pszichológiai alkalmazkodás alsóvégtag-amputációt követően. Orvosi Hetilap, 156: 39 , 1563-1568.

Petkova, J. (2020). Coping strategies against stress - A brief review. Trakia Journal of Sciences, 3, 274-278.

Pongrácz K. (2014). Amputált személyek pszichés jóllétének vizsgálata a fantomfájdalom tükrében. Mentálhigiéné és Pszichoszomatika, 15: 2, 109-138.

Riskó Á. (1999., 2018.05.29). Bevezetés az onkopszichológiába. Jegyzet. Pro Renovanda Cultura Hungariae Alapítvány, Budapest, Pest, Magyarország.

Rosengren, A., Hawken, S., Ôunpuu, S., Sliwa, K., Zubaid, M., Almahmeed, W.A. (2004). Association of psychosocial risk factors with risk of acute myocardial infarction in 11119 cases and 13648 controls from 52 countries (the INTERHEART study): case-control study . The Lancet, 364(9438), 953-962.

Rohánszky M. (2021. április 14). Tüzmadár Alapítvány. Forrás: Tüzmadár Alapítvány: www.tuzmadaralapitvany.hu

Rózsa S., Purebl Gy., Susánszky É., Kő N., Szádóczky E., Réthelyi J., Danis I., Skrabski Á., Kopp M. (2008). A megküzdés dimenziói: A konfliktusmegoldó Kérdőív hazai adaptációja. Mentálhigiéné és Pszichoszomatika 9 (3), 217-241.

Rudas J. (1990). Delfi örökösei - Önismereti csoportokElmélet, módszer, gyakorlat .h.n: Kairosz Kiadó.

Sági A., Szekeres Zs., Köteles F. (2012). Az aerobik pszichológiai jólléttel, önértékeléssel, valamint testi tudatossággal való kapcsolatának empirikus vizsgálata női mintán. Mentálhigiéné és Pszichoszomatika, 13: 3, 273-295.

Sallay V., Martos T., Földvári M., Szabó T., Ittzés A. (2014). A Rosenberg Önértékelés Skála (RSES-H): alternatív fordítás, strukturális invariancia és validitás. Mentálhigiéné és Pszichoszomatika 15 (3), 259-275.

Selye, H. (1956). Endocrine reactions during stress. Anesthesia \& Analgesia, 35: 3, 182-193. 
Stauder A., Balog P., Kovács M., Susánszky É. (2016). A Williams Élet-Készségek stresszkezelő és pszichoszociális készségfejlesztő program magyar adaptációja és 10 éves tapasztalatai. Mentálhigiéné és Pszichoszomatika 17, 2, 81 -95.

Stauder A., Konkolÿ Thege B., Kovács M. E., Balog P., Williams, V. P., \& Williams, R. B. (2010). Worldwide stress: different problems, similar solutions? Cultural adaptation and evaluation of a standardized stress management program in Hungary. International Journal of Behavioral Medicine, 17(1), 25-32.

Stauder A. (2007). Stressz és stresszkezelés . In K. J.V.-O. A., Egészségpszichológia a gyakorlatban (pp.: 153-174). Budapest: Medicina Kiadó.

Stauder A. (2008). Közösségi alapú magatartásorvoslási programok. Az esélyerősítés hatékony módszerei. In M. Kopp (Szerk.), Magyar Lelkiállapot 2008 (pp.: 105-113). Budapest: Semmelweis Kiadó.

Stock, Whitaker, D., Lieberman, M. A. (1981). „A fokális konfliktus modellje”. In Pszichoterápia. Budapest: Gondolat.

Szabó, P. (2010). Egy régi „új” betegség: a testdiszmorfiás zavar (dysmorphophobia). Orvosi Hetilap, 151: 44, 1805-1815.

Szondy, M. (2006). Optimizmus és egészség. Magyar Pszichológiai Szemle, 61: 4, 617-636.

Tasnádi M., Dégi L. Cs. (2016. március 22.). http:// www.cbbjournal.ro/index.php/ro/2016/107-20-1/578-mental-health-protection-of-cancer-patients-through-mindfulness- and-expressive-writing. Forrás: Cognition Brain Behavior - An Interdisciplinary Journal: http://www.cbbjournal.ro

Ursin, H. \& Eriksen, H. R. (2004). The cognitive activation theory of stress. Psychoneuroendocrinology, 29(5), 567-592.

Weiss, J. R., McCabe, M. A., Denning, M. D. (1994). Primary and secondary control among children undergoing medical procedures: Adjustment as a function of coping style. Journal of Consulting and Clinical Psychology, 62, 324-332.

Williams, V. P. \& Williams, R. B. (2006). In control: No more snapping at your family, sulking at work, steaming in the grocery line, seething at meetings, stuffing your frustration. New York: Rodale Press.

Williams, V. P., Brenner, S. L., Helms, M. J. \& Williams, R. B. (2009). Coping skills training to reduce psychosocial risk factors for medical disorders: a field trial evaluating effectiveness in multiple worksites. Journal of Occupational Health, 51(5), 437.

Williams, V. P., Bishop-Fitzpatrick, L., Lane, J. D., Gwyther, L. P., Ballard, E. L., Vendittelli, A. P. (2010). VideoBased Coping Skills (VCS) to reduce health risk and improve psychological and physical well-being in Alzheimer's disease family caregivers. Psychosomatic Medicine, 72(9), 897-904. 


\section{Appendices}

Appendix 1. Presentation of the sessions; topics and objectives

\begin{tabular}{|c|c|c|c|}
\hline & Topic & Objectives & Methods, tools \\
\hline 1. & ,This is who I am....' & $\begin{array}{l}\text { assessing the group members' initial mental } \\
\text { health state; discussing the objectives and the } \\
\text { framework of the planned sessions; setting } \\
\text { the group rules, getting to know one another, } \\
\text { developing a climate of trust, and relaxation }\end{array}$ & $\begin{array}{l}\text { structured exercise facilitating } \\
\text { introduction/ connection in the } \\
\text { group; psychoeducation; trust- } \\
\text { building exercise with experiential } \\
\text { elements; music; questionnaire- } \\
\text { based measurement tools (BSQ, } \\
\text { BASS, WCQ, RSES) }\end{array}$ \\
\hline 2. & $\begin{array}{l}\text {,Self-image - body } \\
\text { image' }\end{array}$ & $\begin{array}{l}\text { explaining the meaning of the sessions; detailed } \\
\text { presentation of the problem-solving technique; } \\
\text { increasing self-esteem; outlining the correlations } \\
\text { between self-image and body image in the light } \\
\text { of mental health; relieving stress and improving } \\
\text { body image }\end{array}$ & $\begin{array}{l}\text { I-statements; psychoeducation; } \\
\text { listening to tales (Wagenaar - Dutch } \\
\text { fable); informal conversations; } \\
\text { dance therapy technique (contact } \\
\text { - technique); five-colored sticks, } \\
\text { music }\end{array}$ \\
\hline 3. & ,Coping' & $\begin{array}{l}\text { schematic presentation of the problem-solving } \\
\text { techniques and testing them; increasing self- } \\
\text { knowledge; becoming aware of the own internal } \\
\text { as well as external resources; achieving a state of } \\
\text { relaxation }\end{array}$ & $\begin{array}{l}\text { whiteboard and markers; } \\
\text { guided imagination exercise; music }\end{array}$ \\
\hline 4. & ,Stress management' & $\begin{array}{l}\text { creating an intimate atmosphere through } \\
\text { providing the opportunity to express personal } \\
\text { feelings; comprehensive presentation of the } \\
\text { WÉK Programme; a detailed description of } \\
\text { stress management tools; living the community } \\
\text { experience and experiencing a sense of support; } \\
\text { creating physical contact }\end{array}$ & $\begin{array}{l}\text { I-statements and informal } \\
\text { conversations; psychoeducation; } \\
\text { whiteboard and markers; music }\end{array}$ \\
\hline 5. & $\begin{array}{l}\text {,Self-knowledge, or } \\
\text { as you know me' }\end{array}$ & $\begin{array}{l}\text { increasing self-knowledge and companionship; } \\
\text { creating a positive atmosphere; experiencing } \\
\text { emotional attunement and the feeling of } \\
\text { empathy/compassion; brief review of the } \\
\text { WEK Programme; acquiring a more in-depth } \\
\text { knowledge of the steps adopted in the various } \\
\text { communication techniques; raising positive } \\
\text { awareness of life }\end{array}$ & $\begin{array}{l}\text { Self-Knowledge Questionnaire } \\
\text { (,This is how you look'); writing } \\
\text { utensils; psychoeducation; poster - } \\
\text { illustrations; music }\end{array}$ \\
\hline 6. & $\begin{array}{l}\text {,Self-expression } \\
\text { in dance steps and } \\
\text { saying good-bye' }\end{array}$ & $\begin{array}{l}\text { creating a supportive atmosphere; relieving } \\
\text { stress; accepting the body image and regaining } \\
\text { control over the body; living positive experiences; } \\
\text { making them aware of their external resources; } \\
\text { practicing the methods of self-expression; } \\
\text { experiencing the conserving force of the } \\
\text { community through physical contact; conducting } \\
\text { a post-test }\end{array}$ & $\begin{array}{l}\text { dance therapy choreography in the } \\
\text { hall of mirrors; music and movement } \\
\text { patterns; symbol exercises; } \\
\text { questionnaire-based measurement } \\
\text { tools (BSQ, BASS, WCQ, RSES) }\end{array}$ \\
\hline
\end{tabular}

